\title{
Riparian old-growth forests provide critical nesting and foraging habitat for Blakiston's fish owl Bubo blakistoni in Russia
}

\author{
Jonathan C. Shaght, Sergei G. Surmach and R. J. Gutiérrez
}

\begin{abstract}
Conservation efforts for Blakiston's fish owl Bubo blakistoni in Russia are limited, partly because habitat use by these rare owls is poorly known. We therefore studied nesting and foraging habitat characteristics of Blakiston's fish owls in Primorye, Russia. We sampled habitat at 14 nest sites, 12 nest stand sites and 13 random sites; we also sampled rivers within 14 fish owl home ranges across our $20,213 \mathrm{~km}^{2}$ study area. We found that large old trees and riparian oldgrowth forest were the primary characteristics of nest and foraging sites, respectively. Large trees were probably used as nest sites because they have cavities large enough to accommodate these birds. Big trees are also important because they are primary sources of large woody debris in rivers, which enhances suitable habitat for salmon, the owl's primary prey. Based on habitat characteristics, nest sites were correctly distinguished from random sites $74 \%$ $($ Kappa $=0.48)$ of the time, nest stands from random sites $56 \%($ Kappa $=0.12)$ of the time, and used sites from available foraging sites $68 \%(\mathrm{Kappa}=0.36)$ of the time. The management and conservation of old-growth forests is essential for sustaining this species because they are central to the owls' nesting and foraging behaviour. Moreover, conservation of these forests sustains habitat for many other species.
\end{abstract}

Keywords Blakiston's fish owl, Bubo blakistoni, habitat characteristics, nest sites, old-growth forest, Primorye, riparian, Russia

\section{Introduction}

$\mathrm{B}$ lakiston's fish owl Bubo blakistoni (hereafter fish owl) has been called 'one of the most interesting birds in the [former] Soviet Union' (Pukinskii, 1973) but despite such distinction it remains little studied (Surmach, 1998; Slaght \& Surmach, 2008). This species, categorized as Endangered on

JONATHAN C. SLAGHT* (Corresponding author) and R. J. GUTIÉRREZ Department of Fisheries, Wildlife, and Conservation Biology, University of Minnesota, Saint Paul, Minnesota, USA. E-mail jslaght@wcs.org

SERGei G. Surmach Institute of Biology and Soils, Russian Academy of Sciences Far East Branch, Vladivostok, Russia

*Current address: Wildlife Conservation Society, Russia Program, 17a Aleutskaya St Apt 31, Vladivostok 690090, Russia

Received 28 February 2012. Revision requested 27 April 2012.

Accepted 11 June 2012. First published online 6 August 2013 the IUCN Red List (BirdLife International, 2008), is associated with riparian forest in Japan, Russia, China and possibly North Korea (Takenaka, 1998; Slaght \& Surmach, 2008). Until recently, the majority of fish owl habitat in Primorye, Russia, was isolated from human contact and scientific investigation because of poor road access and low human density (Surmach, 1998). This situation has changed in recent decades, with natural resource extraction activities expanding into wilderness areas and a subsequent increase in access by logging roads, with concomitant threats to this owl and its habitat (Surmach, 1998; Newell, 2004; Slaght \& Surmach, 2008).

To manage wildlife habitat effectively conservationists and forest managers need to understand the effect of forest exploitation on wildlife (Buchanan et al., 1995). One way this can be done is by investigating habitat use by animals (Johnson, 1980). Previous studies of fish owls in Primorye have suggested that their home ranges are located in river valleys and near waterways having multiple river channels (Spangenberg, 1965; Pukinskii, 1973; Surmach, 1998; Slaght, 2011). Many such areas in Primorye are leased to logging interests, which suggests a high probability of impact on fish owls. We examined selection of nest sites and foraging sites by fish owls in Primorye to gather habitat information that could guide logging concessions to enhance conservation of this globally threatened species and manage its habitat sustainably.

\section{Study area}

Our $20,213 \mathrm{~km}^{2}$ study area was in the central Sikhote-Alin Mountains in Primorye, Russia (Fig. 1). The area is forested and mountainous. Typically, native mixed Korean pine Pinus koraiensis/deciduous forest and Mongolian oak Quercus mongolica/Japanese white birch Betula platyphylla forests are found at lower elevations and spruce-fir Picea and Abies spp. forests at higher elevations (Miquelle et al., 1999). Riparian zones are diverse and often include large Japanese poplar Populus maximowiczii, chosenia Chosenia arbutifolia and cork bark elm Ulmus propinqua, among other species (Pukinskii, 1973).

Rivers are narrow, multi-channelled, fast-flowing, and shallow, and often have warm springs. The latter three features help maintain open water in winter, which allows fish owls to hunt their prey (Slaght \& Surmach, 2008). Of these features, warm springs may be the most important 


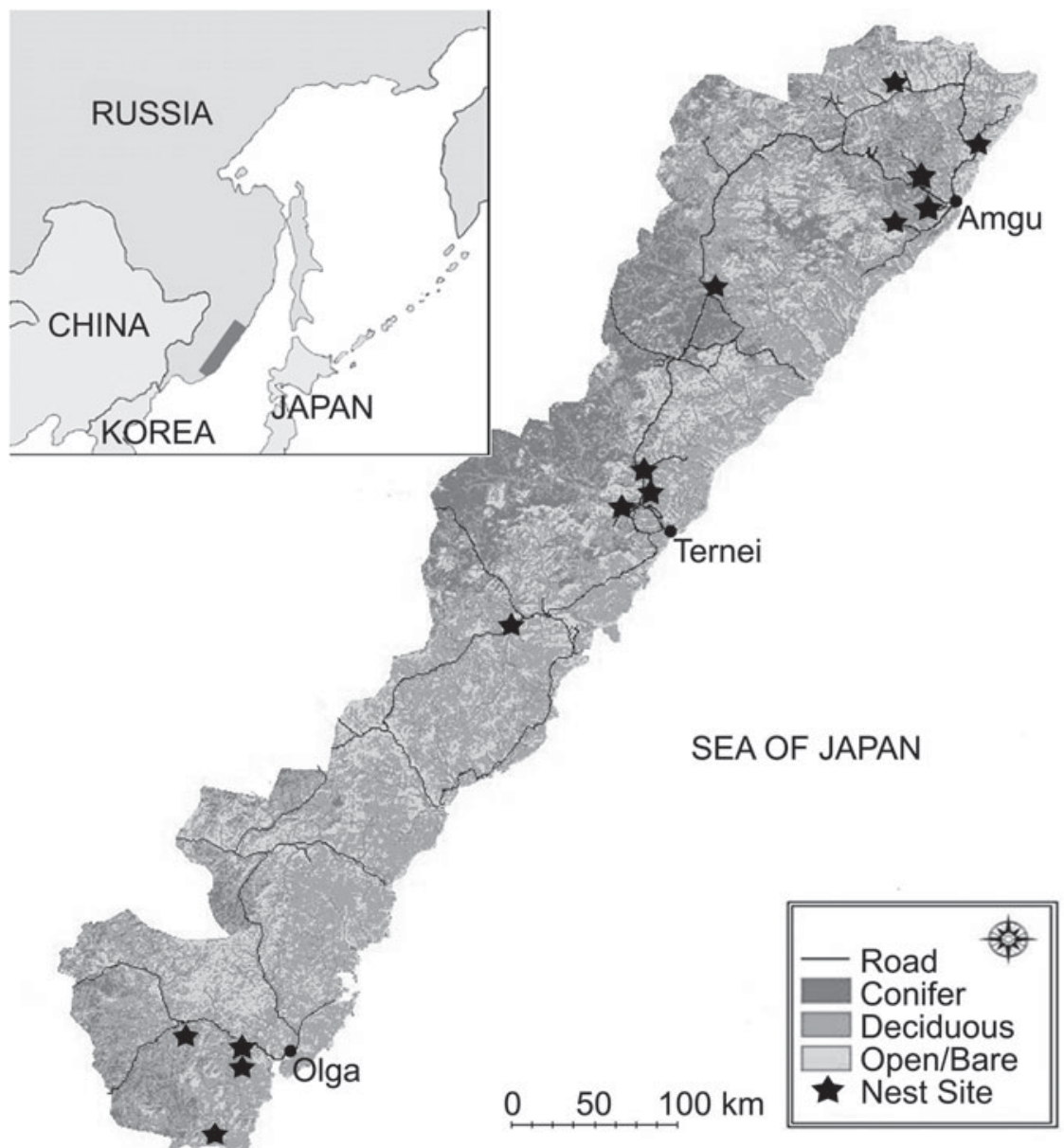

FIG. 1 The study area showing habitat type and location of Blakiston's fish owl Bubo blakistoni nest sites. The inset indicates the location of the main map in Primorye, Russia. for fish owls (Surmach, 1998) because they resist ice accumulation and also attract salmonids in winter (Huusko et al., 2007). All rivers in the study area flow into the Sea of Japan and are used for spawning by salmonids, including chum salmon Oncorhynchus keta, masu salmon Oncorhynchus masou, pink salmon Oncorhynchus gorbuscha, Dolly Varden trout Salvelinus malma and white-spotted char Salvelinus leucomaenis (Semenchenko, 2001).

\section{Methods}

We conducted all habitat and river sampling within river valleys having multiple channels. These are potential fish owl habitat (i.e. the riparian zone) as defined by Slaght, 2011. During 2006-2009 we located nest trees by searching forests where we found fish owl sign (vocalizations, visual detections, feathers, tracks in snow). We delineated fish owl home ranges encompassing these trees using geographical positioning system (GPS) telemetry and a synoptic model of space use (Horne et al., 2008; Slaght, 2011). Within each such home range we measured habitat characteristics within three 0.2 ha ( $25 \mathrm{~m}$ radius) plots. We centred habitat plots on the nest tree (nest site), on a tree $50 \mathrm{~m}$ in a random direction from the nest tree (nest stand site), and on a tree $\leq 1,500 \mathrm{~m}$ in a random direction from the nest tree (random site), given that it was still within the home range and within the riparian zone.

We conducted habitat and prey surveys within rivers in six of the nine major river drainages in the study area during summer 2009, prior to delineation of fish owl home ranges using GPS telemetry (Slaght, 2011). Because of this we selected distance to random sites $(\leq 1,500 \mathrm{~m})$ based on limited VHF telemetry data collected in 2007 , which showed linear movements up to c. $1,500 \mathrm{~m}$ from the nest tree in winter. We centred nest stand sites and random sites on trees with c. $59 \mathrm{~cm}$ diameter at breast height $(\mathrm{DBH}$; Dilworth, 1981), which was the minimum size for nest trees reported for fish owls in Japan (Takenaka, 1998). We did this because large trees in nest sites influence habitat characteristics, and centring plots on trees reduces that influence on comparisons between sites. We also wanted to place sampling locations within areas that were potentially available as nest sites.

We used sampling methods typically used in other habitat studies of birds (Seamans, 1994; Martin et al., 1997; LaHaye \& Gutiérrez, 1999). At each site we recorded species 
and DBH of every tree $>15 \mathrm{~cm}$ within $12.5 \mathrm{~m}$ of plot centre, and species and DBH of every tree $>40 \mathrm{~cm}$ within $25 \mathrm{~m}$ of plot centre. We measured canopy cover using a densitometer and ground cover using a density board and recorded the number of logs $>15 \mathrm{~cm}$ in diameter at the smallest end. We collected additional data from each nest tree, including total height, nest height (measured with a hypsometer), qualitative condition (healthy, weakened, declining, dead $<_{2}$ years, dead $>_{2}$ years; sensu Brandt et al., 2003), and species. 'Healthy' trees had full crowns, 'weakened' trees had less than full crowns (some damage), and 'declining' trees had poor crowns (severe damage; Brandt et al., 2003). We also classified nest type (broken-top cavity, side cavity, other). Broken-top cavities were typically depressions formed when a trunk or large branch broke and the exposed surfaces decayed downward over time. Side cavities were natural holes in the side of a trunk (i.e. where side branches fell off). 'Other' was a category for non-cavity nest structures (e.g. cliff ledge, old raptor nest). We minimized disturbance to resident fish owls by conducting all vegetation measurements at nest sites and nest stand sites during August and September, well after chicks had fledged (May-June; Slaght \& Surmach, 2008) and when birds were no longer in the immediate area.

We collected data on river characteristics from two plots (used and available) within each fish owl home range ( $\mathrm{n}=14$ nest sites and 14 available sites) to assess whether fish owls select nest sites near stretches of river that have higher abundance of prey. As movement data were not available at the time of sampling we subjectively defined 'used' river stretches as those closest to the nest tree (because fish owls often hunt close to the nest) and 'available' river stretches as those closest to our random habitat site (see above). Subsequent GPS locations from tagged birds and sign revealed that $79 \%(\mathrm{n}=11)$ of locations categorized as 'used' were in fact used by fish owls during the study period, and $21 \%(\mathrm{n}=3)$ of 'available' locations were used by fish owls, which validated our rationale for selection of sample locations. We conducted snorkel surveys of $100 \mathrm{~m}$ stretches of river to sample potential fish prey (O'Neal, 2007). The point on the river nearest the nest tree or random point was the centre of our $100 \mathrm{~m}$ sample transect. We started all snorkel surveys downriver from this centre point. We stopped every $20 \mathrm{~m}$ to record number of fish, fish species and size (visual estimation; small $\leq 15 \mathrm{~cm}$, medium $\geq 15$ and $<30 \mathrm{~cm}$, large $\geq 30 \mathrm{~cm}$ ). We recorded channel depth (mean and maximum), channel width, water flow (in m second $\mathrm{d}^{-1}$, using a flowmeter), riffle type (cascade, rapid, glide), substrate (sand, pebble, cobble, bedrock) and water temperature. We also estimated the amount of nearby riparian old-growth forest within a $50 \mathrm{~m}$ radius surrounding the starting point, using remote sensing (Slaght, 2011). We measured this because researchers have suggested a positive relationship between riparian old-growth forest and large woody debris in rivers, which is thought to improve habitat for salmonids during some life stages (Lunetta et al., 1997; Luck et al., 2010).

We used linear discriminant analyses (Fisher, 1936) to identify important variables associated with fish owl nest and foraging site selection. We conducted habitat and river analyses separately. We checked assumptions of discriminant analysis and transformed data prior to analysis when necessary. We used Levene's test to confirm homogeneity of variance, and calculated a Shapiro-Wilk statistic $(W)$ to test normality. One habitat variable (proportion of deciduous forest) was highly skewed towards 1.0 and could not be transformed to a normal distribution. One river variable (amount of riparian old-growth forest within a $50 \mathrm{~m}$ buffer) was highly skewed towards $o$ and similarly could not be transformed. Therefore, we did not transform these variables but subsequently tested multivariate normality by conducting discriminant analysis and assessing resulting canonical scores as recommended by McGarigal et al. (2000). Tests for equal covariance are difficult to conduct formally (Quinn \& Keough, 2002) so we conducted all analyses again using quadratic discriminant analysis, which produces more reliable results if the equal covariance assumption of linear discriminant analysis is violated (McGarigal et al., 2000). Results of linear and quadratic discriminant analyses were identical; thus we used linear discriminant analysis results for inference.

We evaluated sample size requirements following Rule C in McGarigal et al. (2000), which was based on simulation experiments by Williams \& Titus (1988). This rule states that sample sizes for discriminant function analyses should minimally comply with $N \geq{ }_{3} P$, where $N$ is number of observations per group and $P$ is number of variables. Because $N$ in our data was 12-14 observations (sites), $P$ should be $\leq 4$. For habitat data we started with 30 variables and removed 23 that were correlated with other variables $(r \geq 0.70)$ or those we deemed unlikely to be informative for fish owls (e.g. based on our a priori design we sampled variables that did not occur at all sites, so they would probably not provide much information). Following recommendations from McGarigal et al. (2000) we then partitioned the remaining seven habitat variables into two smaller groups, thereby satisfying sample size requirements of $N \geq{ }_{3} P$. The first group depicted habitat structure (four variables: largest tree $\mathrm{DBH}$, number of snags, mean plot $\mathrm{DBH}$, canopy cover). The second group depicted habitat composition (three variables: $\%$ of deciduous forest, number of tree species, \% of medium-sized trees $50-70 \mathrm{~cm} \mathrm{DBH})$.

We measured 31 variables associated with rivers and removed 23 that were correlated with other variables $(r \geq 0.70)$ or that we decided retrospectively might be uninformative. We partitioned the remaining eight river variables into two groups. The first group depicted river structure (four variables: water flow, riffle, substrate, 
TABLE 1 Comparisons of habitat characteristics within 14 Blakiston's fish owl Bubo blakistoni home ranges in Primorye, Russia (Fig. 1), in summer 2009, with F-statistic and associated P used to test the null hypothesis that all sites were the same.

\begin{tabular}{|c|c|c|c|c|c|}
\hline & Nest site ${ }^{1}$ & Nest stand site ${ }^{2}$ & Random site ${ }^{3}$ & & \\
\hline Variable & Mean \pm SE & Mean \pm SE & Mean \pm SE & $F$ & $\mathrm{P}$ \\
\hline$\overline{\mathrm{DBH}}$ of largest tree $(\mathrm{cm})$ & $121.71 \pm 8.55$ & $110.75 \pm 9.23$ & $82.36 \pm 8.87$ & 5.35 & 0.01 \\
\hline Mean DBH $(\mathrm{cm})$ & $43.35 \pm 2.93$ & $42.42 \pm 3.16$ & $38.99 \pm 3.04$ & 0.57 & 0.57 \\
\hline No. of snags & $3.14 \pm 0.59$ & $1.50 \pm 0.64$ & $0.92 \pm 0.62$ & 3.60 & 0.04 \\
\hline$\%$ canopy cover & $0.80 \pm 0.23$ & $0.83 \pm 0.24$ & $0.85 \pm 0.23$ & 1.16 & 0.33 \\
\hline$\%$ deciduous trees & $0.92 \pm 0.04$ & $0.87 \pm 0.05$ & $0.89 \pm 0.05$ & 0.29 & 0.75 \\
\hline$\%$ of trees with DBH $50-70 \mathrm{~cm}$ & $0.17 \pm 0.03$ & $0.16 \pm 0.04$ & $0.17 \pm 0.04$ & 0.01 & 0.99 \\
\hline No. of tree species & $3.83 \pm 0.43$ & $3.73 \pm 0.45$ & $2.77 \pm 0.42$ & 1.91 & 0.16 \\
\hline
\end{tabular}

${ }^{1}$ Characteristics centred on nest tree $(n=14)$

${ }^{2}$ Characteristics centred on tree c. $59 \mathrm{~cm} \mathrm{DBH}$ at $50 \mathrm{~m}$ from nest tree $(\mathrm{n}=12)$

${ }^{3}$ Characteristics centred on tree c. $59 \mathrm{~cm} \mathrm{DBH} \leq 1,500 \mathrm{~m}$ from nest tree $(\mathrm{n}=13)$

amount of riparian old-growth forest within a $50 \mathrm{~m}$ buffer). The second group depicted characteristics of the potential prey community (four variables: species diversity, number of small masu salmon, total fish count, number of mediumsized Dolly Varden trout).

We conducted separate forward stepwise discriminant analyses on each group, with $F$-to-enter and $F$-to-remove set at 0.15 , and used Wilks' Lambda as the criterion for variable inclusion (McGarigal et al., 2000). For habitat analyses prior probabilities were adjusted to group size (nest site vs random site: 0.52 and 0.48 , respectively; nest stand site vs random site: 0.48 and 0.52 , respectively), whereas for river analyses probabilities were equal (0.50) among groups. We estimated all classification accuracies using a jackknife procedure. We assessed classification accuracies of discriminant analysis by measuring total accuracy (\%) and Cohen's Kappa statistic, a measure used to calculate chance-corrected classification rates (Titus et al., 1984). We estimated the eigenvalue $(\lambda$; a measure of group separation, with larger values indicating greater separation), the canonical correlation coefficient $\left(R_{c}\right.$; a measure of correlation among variables in the range $0-1$, where $o$ is no relationship and 1 is complete association), and the squared canonical correlation $\left(R_{c}^{2}\right.$; a measure of variation explained by the group means). We also used analysis of variance (ANOVA) to compare class means of habitat and river variables.

We conducted statistical analyses in $R \quad v$. 2.11.o ( $\mathrm{R}$ Development Core Team, 2010) using the MASS (Venables \& Ripley, 2002) and KlaR (Weihs et al., 2005) libraries. For habitat we conducted one analysis comparing nest sites to random sites and a second analysis comparing nest stand sites to random sites. For river characteristics we conducted a single analysis comparing used and available sites.

\section{Results}

We measured seven habitat variables at 14 nest sites, 12 nest stand sites, and 13 random sites within 14 fish owl home ranges (Table 1). Our general description of nest trees was based on these 14 sites, plus one additional nest tree not included in nest site analysis because additional data were not available. Fish owls used large riparian old-growth trees for nest trees: either Japanese poplar $(53 \%, \mathrm{n}=8)$, chosenia $(33 \%, \mathrm{n}=5)$, or cork bark elm $(13 \%, \mathrm{n}=2)$. Nest tree condition was either declining $(47 \%, \mathrm{n}=7)$, dead $>2$ years $(33 \%, \mathrm{n}=5)$, or weakened $(20 \%, \mathrm{n}=3)$. All nests $(100 \%$, $\mathrm{n}=15$ ) were in broken-top cavities. Mean nest tree DBH was $115.3 \pm$ SE $6.5 \mathrm{~cm}$ (range 74-150), mean nest tree height was $18.1 \pm$ SE $1.5 \mathrm{~m}$ (range 8.6-27.1), and mean nest cavity height was 9.3 \pm SE $1.0 \mathrm{~m}$ (range 4-16.8). Broken-top cavities were often located where the main bole had broken off and banner limbs continued to add vertical growth to the tree (Rockweit, 2008), hence mean nest height was c. half the mean nest tree height. Nearly half $(47 \%, n=7)$ of all nests were in residual trees and snags, which were much older than the surrounding forest (sensu Hunter \& Bond, 2001). Remaining nest trees were in forest patches having $>2$ trees with $\mathrm{DBH} \geq 80 \mathrm{~cm}(53 \%, \mathrm{n}=8)$.

We measured eight river variables at 14 locations near nest trees (used sites) and 14 random locations (available sites) within 14 fish owl home ranges (Table 2). All used sites were river channels characterized by shallow depth $(\bar{x}=21.0 \pm \mathrm{SE} 2.0 \mathrm{~cm})$, swift flow $\left(1.8 \pm \mathrm{SE} 0.4 \mathrm{~m} \mathrm{~second}^{-1}\right)$, predominantly glide riffle ( $48 \pm$ SE $10 \%)$, and predominantly cobble substrate $(64 \pm$ SE $6 \%)$. Mean maximum river depth was $78.0 \pm$ SE $7.0 \mathrm{~cm}$. Available sites were similarly characterized by shallow depth $(\bar{x}=23.0 \pm \mathrm{SE} 2.0 \mathrm{~cm})$, with swift flow $\left(2.3 \pm 0.4 \mathrm{~m} \mathrm{~second}^{-1}\right)$, predominantly glide riffle $(56 \pm$ SE $8 \%)$, and predominately cobble substrate $(54 \pm$ SE $7 \%$ ). Mean maximum river depth at available sites was $83.0 \pm \mathrm{SE} 11.0 \mathrm{~cm}$.

We found nine species of fishes during surveys, with a slightly higher number of species at available sites $(\bar{x}=3.21 \pm$ SE 0.39$)$ than used sites $(\bar{x}=2.93 \pm$ SE 0.27$)$. Masu salmon (small and medium) were present at all used sites $(\mathrm{n}=14$ sites each) and most available sites (small 
TABlE 2 Comparisons of river characteristics within 14 Blakiston's fish owl home ranges in Primorye, Russia (Fig. 1), summer 2009, with F-statistic and associated P used to test the null hypothesis that used and available sites were the same.

\begin{tabular}{|c|c|c|c|c|c|}
\hline \multirow[b]{2}{*}{ Variable } & \multirow[b]{2}{*}{ Unit } & \multirow{2}{*}{$\frac{\text { Used site }^{1}}{\text { Mean } \pm \text { SE }}$} & \multicolumn{3}{|l|}{ Available site $^{2}$} \\
\hline & & & Mean \pm SE & $F$ & $\mathrm{P}$ \\
\hline Mean water flow & $\mathrm{m} \mathrm{second}^{-1}$ & $1.75 \pm 0.37$ & $2.34 \pm 0.37$ & 1.20 & 0.28 \\
\hline \multirow[t]{3}{*}{ Riffle type } & $\%$ glide & $0.48 \pm 0.10$ & $0.51 \pm 0.10$ & 0.07 & 0.80 \\
\hline & $\%$ rapid & $0.34 \pm 0.10$ & $0.31 \pm 0.10$ & 0.03 & 0.88 \\
\hline & $\%$ cascade & $0.19 \pm 0.06$ & $0.17 \pm 0.06$ & 0.03 & 0.87 \\
\hline \multirow[t]{4}{*}{ Substrate } & $\%$ cobble & $0.64 \pm 0.06$ & $0.56 \pm 0.08$ & 0.53 & 0.47 \\
\hline & $\%$ pebble & $0.21 \pm 0.07$ & $0.23 \pm 0.07$ & 0.05 & 0.83 \\
\hline & $\%$ boulder & $0.11 \pm 0.06$ & $0.11 \pm 0.07$ & 0.00 & 1.00 \\
\hline & $\%$ sand & $0.04 \pm 0.02$ & $0.09 \pm 0.04$ & 1.50 & 0.23 \\
\hline Riparian old-growth & $\%$ & $0.07 \pm 0.02$ & $0.01 \pm 0.02$ & 4.43 & 0.05 \\
\hline Fish & Count & $214.07 \pm 39.45$ & $191.50 \pm 53.01$ & 0.12 & 0.74 \\
\hline Species & Count & $2.93 \pm 0.29$ & $3.21 \pm 0.29$ & 0.48 & 0.48 \\
\hline Small masu salmon & Count & $93.71 \pm 11.94$ & $91.71 \pm 11.94$ & 0.01 & 0.90 \\
\hline Medium trout & Count & $11.29 \pm 5.02$ & $13.29 \pm 5.02$ & 0.08 & 0.78 \\
\hline
\end{tabular}

${ }^{1}$ Rriver characteristics measured along $100 \mathrm{~m}$ of river closest to the nest tree

${ }^{2}$ River characteristics measured along $100 \mathrm{~m}$ of river closest to the random vegetation site

$\mathrm{n}=13$ sites; medium $\mathrm{n}=12$ sites). Small Dolly Varden trout were present at seven used and four available sites; medium Dolly Varden trout were present at 10 used and nine available sites. There were more fish at used $(\bar{x}=214.07 \pm$ SE 39.45, range 61-576) than available sites $(\bar{x}=191.50 \pm$ SE 53.01, range $3-788)$.

Our habitat data met assumptions of multivariate normality for nest $(W=0.980, \mathrm{P}=0.976)$, nest stand ( $W=0.899, \quad \mathrm{P}=0.131)$, and random sites $(W=0.898$, $\mathrm{P}=0.175)$. Wilks' Lambda indicated that two variables, both related to habitat structure, met criteria for inclusion in a discriminant analysis for nest sites: largest tree $\mathrm{DBH}$ $(F=13.81, \mathrm{df}=1, \mathrm{P}=0.001)$ and number of snags $(F=9.15$, $\mathrm{df}=1, \mathrm{P}=0.018)$. The discriminant analysis indicated that $81 \%$ of the variation between nest and random sites could be explained by the largest tree $\mathrm{DBH}$ and number of snags $\left(\lambda=4.37, R_{\mathrm{c}}=0.90, R_{c}^{2}=0.81\right)$, with nearly all variation (79\%) because of the largest tree DBH $\left(\lambda=3.71, R_{c}=0.89\right.$, $\left.R_{c}^{2}=0.79\right)$. When compared to random sites, nest site categorization accuracy was $74 \%($ Kappa $=0.48)$. When compared to random sites, nest stand sites were categorized accurately $56 \%$ of the time (Kappa =0.12). ANOVA indicated that the largest tree $\mathrm{DBH}$ at nest sites was greater than at random sites $(F=5.35, \mathrm{df}=2, \mathrm{P}=0.009)$ and that there were more snags at nest sites than either nest stand sites or random sites $(F=3.60, \mathrm{df}=2, \mathrm{P}=0.038$; Table 1 ).

Our river data met assumptions of multivariate normality for used $(W=0.88, \mathrm{P}=0.07)$ and available sites $(W=0.945, \mathrm{P}=0.482)$. Wilks' Lambda indicated that two variables met criteria for inclusion in a discriminant analysis for distinguishing potential fish owl foraging sites: nearby riparian old-growth forest $(F=4.43, \mathrm{df}=1$, $\mathrm{P}=0.045)$ and percent cobble substrate $(F=3.55, \mathrm{df}=1$, $\mathrm{P}=0.131)$. Discriminant analysis showed that $73 \%$ of the variation between used and available sites could be explained by nearby riparian old-growth forest and cobble substrate $\left(\lambda=2.71, R_{c}=0.85, R_{c}^{2}=0.73\right)$, with nearly all of this $(68 \%)$ because of nearby riparian old-growth forest alone $\left(\lambda=2.10, R_{c}=0.82, R_{c}^{2}=0.68\right)$. Compared to available sites, overall categorization accuracy of used sites was $68 \%($ Kappa $=0.36)$. ANOVA showed that used sites had a higher proportion of riparian old-growth forest $(\bar{x}=7 \% \pm \mathrm{SE} 2 \%)$ than available sites $(\bar{x}=1 \% \pm \mathrm{SE} 2 \%$; $F=3.94, \mathrm{df}=1 ; \mathrm{P}=0.058)$.

\section{Discussion}

The types and characteristics of nest trees that we observed fish owls using were consistent with previous descriptions from Russia and Japan. In Russia mean nest tree $\mathrm{DBH}$ from Takenaka (1998) and Andreev (2009) combined was 107.3 \pm SE 10.7 $(\mathrm{n}=3$, values were 90, 105, and $127 \mathrm{~cm})$. In Japan Takenaka (1998) found mean nest tree DBH to be $95.5 \pm \mathrm{SE} 5.3 \mathrm{~cm}(\mathrm{n}=12$; range 59-123) and Yamamoto (1999) reported a range of nest tree $\mathrm{DBH}$ of $80-130 \mathrm{~cm}$ (sample size unspecified).

Although we found few differences between used and available sites within fish owl home ranges, riparian oldgrowth trees were clearly the most important discriminating characteristics of both nest and foraging sites. Snags were a secondary indicator of nesting habitat, and cobble substrate in rivers was a secondary indicator of suitable foraging habitat. The number of large trees and percentage of riparian old-growth forest accounted for most of the variation among classes and featured prominently in plot discrimination at nest and foraging sites, respectively. The squared canonical correlation $\left(R_{c}^{2}\right)$ provided strong evidence 
that the gradient of riparian old growth and number of snags were a function of the difference between these characteristics at nest and random sites. This suggested that tree size was sufficient to discriminate potential fish owl nest sites from random locations given a suitable landscape (Slaght, 2011). The importance of this single habitat feature was supported by our comparisons of nest stand sites with random sites, which showed low predictive power $($ Kappa $=0.12)$, suggesting that without the large trees at nest sites our discriminant analysis might not distinguish utilized fish owl habitat from random sites.

Although it is intuitive that large trees would be important for nesting (because fish owls are large birds that require a large nesting substrate) the association between surrounding riparian old-growth forest and fish owl foraging sites was unexpected. Because there was no difference between the distances of nest trees or random habitat sites to used $(\bar{x}=72.5 \pm \mathrm{SE} 13.3 \mathrm{~m})$ or available $(\bar{x}=83.7 \pm$ SE $13.3 \mathrm{~m} ; \mathrm{n}=14)$ foraging sites the relationship between old-growth riparian habitat and fish owl foraging sites was not simply an artefact of distance to nest. River channel complexity, identified by Slaght (2011) as an important indicator of suitable fish owl landscape habitat, has also been associated with large woody debris in waterways (Lunetta et al., 1997; Luck et al., 2010). Fallen trees caused by natural senescence and storms can clog waterways and induce channel formation and subsequently increase diversity of freshwater habitat by creating a mosaic of fast-moving channels interspersed with slow-moving, deep pools (Reeves et al., 1991). This can result in ideal habitat for salmonids of varying life stages because large woody debris is strongly correlated with salmonid abundance and survival, particularly in winter (Hicks et al., 1991; Reeves et al., 1991). Thus, the presence of old-growth forest along waterways in home ranges of fish owls increases the probability of suitable salmonid habitat and fish owl foraging habitat.

Tree size alone is inadequate to identify a fish owl nest site because trees must also be in suitable condition for nesting. All nest trees that we found were in some stage of deterioration, and all of them had a suitable cavity for a fish owl nest. Similarly, the mere presence of old-growth forest along river banks does not necessarily imply suitable foraging habitat because rivers that are too deep, broad or swift may preclude accumulation of large woody debris. Nevertheless, riparian old growth seems to be a good indicator of nesting and foraging sites for fish owls, provided it is adjacent to streams of suitable size and structure (as identified above).

Riparian old-growth forest appears to be important for fish owls because it provides nest trees, suitable nest stands, the potential for recruitment of nest trees, and possible enhancement of foraging sites by introducing large woody debris into waterways. Hence conservation of riparian oldgrowth forests is important for conservation of fish owls because the age of trees is a requisite for conditions suitable for nest sites (e.g. a large tree bole broken in a wind storm takes many years to decay sufficiently to create a suitable nest cavity; LaHaye \& Gutiérrez, 1999). We also recommend that specific locations within riparian zones that replicate the habitat conditions we observed be protected from timber harvesting and other disturbances such as road construction, to allow development or maintenance of suitable nest stands. Although fish owls show some plasticity in nest site selection, they appear to prefer broken-top cavities because of their size. Therefore potential nest trees such as large specimens of Japanese poplar, chosenia, cork bark elm and other species that are declining in vigour should not be removed from a forest. In addition, retention of smaller individuals of these species is needed to sustain recruitment of future nest trees.

Fish owls have used nest boxes successfully on both Hokkaido Island, Japan (Yamamoto, 1999) and Kunashir Island, Russia (Berzan, 2000). Such artificial nest sites may be appropriate for parts of their former range that contain suitable riverine forest conditions but lack suitable nest trees, such as in south-western Primorye where the species once occurred but is either no longer present or is scarce (Surmach, 1998). Nest boxes are only part of a potential conservation solution, however, as human activities in the region may negate any possible benefits resulting from next box installation. For example, all owls (including fish owls) are considered competitors for fur-bearing mammals by local trappers and are regularly shot (Surmach, 1998). Therefore the installation of conspicuous nest boxes may actually contribute to owl mortality. A possible solution would be to install nest boxes in protected areas (such as the recently established Land of the Leopard National Park), where human use is restricted.

The importance of riparian old-growth forest along waterways used for foraging also underscores the importance of enforcing stream buffer zone protection, codified in Russian law, between rivers and roads to preserve the recruitment of large woody debris (Slaght, 2011). Retention of habitat for fish owls will also maintain habitat for many other species associated with riparian old-growth forests in the Russian Far East.

\section{Acknowledgements}

We thank our field assistants S. Avdeyuk, A. Katkov and K.T. Gutiérrez-Westcott. V. and A. Volkov provided logistical support in the field. T. Arnold, M. Bauer, P. Kapfer, D. Miquelle, and two anonymous reviewers provided constructive advice. G. Matsumori helped with Japanese translations. The Wildlife Conservation Society-Russia Programme provided logistical support. Considerable logistical and financial support was provided 
by the Amur-Ussuri Centre for Avian Biodiversity. Additional funding was provided by the Bell Museum of Natural History, Columbus Zoo, Denver Zoo, Disney Worldwide Conservation Fund, Minnesota Zoo, National Aviary, National Birds of Prey Trust, and US Forest ServiceInternational Programs. JCS was substantially supported by the University of Minnesota non-sponsored account to RJG, the Minnesota Agriculture Experiment Station, University of Minnesota Doctoral Dissertation Fellowship, the Gordon Gullion Scholarship, the Leigh H. Perkins Fellowship, and a Wildlife Conservation Society Research Fellowship. All of our methods for capturing, handling, and using telemetry on fish owls were approved by the University of Minnesota's Institutional Animal Care and Use Committee (IACUC Study Protocol Number 0610A95546).

\section{References}

Andreev, A.V. (2009) The Blakiston's fish owl (Bubo blakistoni) at north-eastern limits of is range. Osnabrücker Naturwissenschaftliche Mitteilungen, 35, 47-54.

BerZan, A.P. (2000) Observation of Blakiston's fish owl (Ketupa blakistoni) on Kunashir Island (Kuril Islands) and methods to encourage breeding. Russkii Ornitologicheskii Zhurnal Ekspress-vypusk, 119, 3-12.

BirdLife International (2008) Ketupa blakistoni. In IUCN 2011. IUCN Red List of Threatened Species v. 2011.2. Http://www. iucnredlist.org [accessed 14 February 2012].

Brandt, J.P., Cerezke, H.F., Mallett, K.I., Volney, W.J.A. \& Weber, J.D. (2003) Factors affecting trembling aspen (Populus tremuloides Michx.) health in the boreal forest of Alberta, Saskatchewan, and Manitoba, Canada. Forest Ecology and Management, 178, 287-300.

Buchanan, J.B., Irwin, L.L. \& McCutchen, E.L. (1995) Withinstand nest site selection by spotted owls in the eastern Cascades. Journal of Wildlife Management, 59, 301-310.

Dilworth, T. (1981) Log Scaling and Timber Cruising. Oregon State University Press, Corvallis, USA.

Fisher, R.A. (1936) The use of multiple measurements in taxonomic problems. Annals of Eugenics, 7, 179-188.

Hicks, B.J., Hall, J.D., Bisson, P.A. \& Sedell, J.R. (1991) Responses of salmonids to habitat changes. In Influences of Forest and Rangeland Management on Salmonid Fishes and their Habitats (ed. W.R. Meehan), pp. 483-518. American Fisheries Society Special Publication 19, Bethesda, USA.

Horne, J.S., Garton, E.O. \& Rachlow, J.L. (2008) A synoptic model of animal space use: simultaneous estimation of home range, habitat selection, and inter/intra-specific relationships. Ecological Modelling, 214, 338-348.

Hunter, J.E. \& BOND, M.L. (2001) Residual trees: wildlife associations and recommendations. Wildife Society Bulletin, 29, 995-999.

Huusko, A., Greenberg, L., Stickler, M., Linnansaari, T., Nykanen, M., Vehanen, T. et al. (2007) Life in the ice lane: the winter ecology of stream salmonids. River Research and Applications, 23, 469-491.

Johnson, D.H. (1980) The comparison of usage and availability measurements for evaluating resource preference. Ecology, 61, 65-71.

LaHaye, W.S. \& Gutiérrez, R.J. (1999) Nest sites and nesting habitat of the northern spotted owl in northwestern California. Condor, 101, 324-330.
Luck, M., Maumenee, N., Whited, D., Lucotch, J., Chilcote, S., LorAnG, M. et al. (2010) Remote sensing analysis of physical complexity of North Pacific Rim rivers to assist wild salmon conservation. Earth Surface Processes and Landforms, 35, 1330-1343.

Lunetta, R.S., Cosentino, B.L., Montgomery, D.R., Beamer, E.M. \& BeEchie, T.J. (1997) GIS-based evaluation of salmon habitat in the Pacific Northwest. Photogrammetric Engineering and Remote Sensing, 63, 1219-1229.

Martin, T.E., Paine, C., Conway, C.J., Hochachka, W.M., Allen, P. \& Jenkins, W. (1997) Breeding Biology Research and Monitoring Database (BBIRD) Field Protocols. Montana Cooperative Wildlife Research Unit, Missoula, USA. Http://www. umt.edu/bbird/ [accessed 18 September 2009].

McGarigal, K., Cushman, S. \& Stafford, S. (2000) Multivariate Statistics for Wildlife and Ecology Research. Springer, New York, USA.

Miquelle, D.G., Merrill, T.W., Dunishenko, Y.M., Smirnov, E.N., Quigley, H.B., Pikunov, D.G. \& Hornocker, M.G. (1999) A habitat protection plan for the Amur tiger: developing political and ecological criteria for a viable land-use plan. In Riding the Tiger: Tiger Conservation in HumanDominated Landscapes (eds J. Seidensticker, S. Christie \& P. Jackson), pp. 273-295. Cambridge University Press, Cambridge, UK. Newell, J. (2004) The Russian Far East: a Reference Guide for Conservation and Development. Daniel and Daniel Publishers, McKinleyville, USA.

O’Neal, J.S. (2007) Snorkel surveys. In Salmonid Field Protocols Handbook: Techniques for Assessing Status and Trends in Salmon and Trout Populations (eds D.H. Johnson, B.M. Shrier, J.S. O’Neal \& T.N. Pearsons), pp. 325-340. American Fisheries Society and State of the Salmon, Bethesda, USA.

PukinskiI, Y.B. (1973) Ecology of Blakiston's Fish Owl in the Bikin river basin. Byulletin Moskovskovo Obshchestva Ispytatelei Prirody Otdel Biologii, 78, 40-47.

Quinn, G.P. \& Keough, M.J. (2002) Experimental Design and Data Analysis for Biologists. Cambridge University Press, New York, USA.

R Development Core Team (2010) R: A Language and Environment for Statistical Computing. R Foundation for Statistical Computing. Http://www.R-project.org/ [accessed 15 October 2010].

Reeves, G.H., Hall, J.D., Roelofs, T.D., Hickman, T.L. \& B AKER, C.O. (1991) Rehabilitating and modifying stream habitats. In Influences of Forest and Rangeland Management on Salmonid Fishes and their Habitats (ed. W.R. Meehan), pp. 519-557. American Fisheries Society Special Publication 19, Bethesda, USA.

Rockweit, J.T. (2008) Potential effects of nest structure and weather on microclimate of northern spotted owl nests. MSc thesis. University of Minnesota, St. Paul, USA.

Seamans, M.E. (1994) Breeding habitat ecology of the Mexican spotted owl in the Tularosa mountains, New Mexico. MSc thesis. Humboldt State University, Arcata, USA.

Semenchenko, A.Y. (2001) Species and structure of fish populations in Primorye rivers. In V.Y. Levanidov's Biennial Memorial Readings, Vol. 1 (ed. E.A. Makarchenko), pp. 217-228. Dalnauka, Vladivostok, Russia.

SLAGHT, J.C. (2011) Management and conservation implications of Blakiston's fish owl (Bubo blakistoni) resource selection in Primorye, Russia. PhD dissertation. University of Minnesota, St. Paul, USA.

Slaght, J.C. \& Surmach, S.G. (2008) Biology and conservation of Blakiston's fish owls in Russia: a review of the primary literature and assessment of the secondary literature. Journal of Raptor Research, $42,29-37$.

Spangenberg, Y.P. (1965) Birds of the Iman River basin. Sbornik Trudov Zoologicheskovo Museya MGU, 9, 98-202. 
Surmach, S.G. (1998) Present status of Blakiston's fish owl (Ketupa blakistoni Seebohm) in Ussuriland and some recommendations for protection of the species. Report of the Pro Natura Foundation, 7, 109-123.

TAKenaKa, T. (1998) Distribution, habitat environments, and reasons for reduction of the Endangered Blakiston's Fish Owl in Hokkaido, Japan. PhD thesis. Hokkaido University, Sapporo, Japan.

Titus, K., Mosher, J.A. \& Williams, B.K. (1984) Chance-corrected classification for use in discriminant analysis: ecological applications. American Midland Naturalist, $111,1-7$.

Venables, W.N. \& Ripley, B.D. (2002) Modern Applied Statistics with $S$, 4th edition. Springer, New York, USA.

Weins, C., Ligges, U., LuebKe, K. \& RaAbe, N. (2005) klaR Analyzing German Business Cycles. In Data Analysis and Decision Support (eds D. Baier, R. Decker \& L. Schmidt-Thieme), pp. 335-343. Springer-Verlag, Berlin, Germany.
Williams, B.K. \& Titus, K. (1988) Assessment of sampling stability in ecological applications of discriminant analysis. Ecology, 69, $1275-1285$.

Yamamoto, S. (1999) The Blakiston's Fish Owl. Hokkaido Shimbun Press, Sapporo, Japan.

\section{Biographical sketches}

Jonathan C. Slaght is interested in animal distributions, particularly of birds, in the Russian Far East, and in identifying the resources and conservation issues that influence those distributions. SERGEI G. SURMACH's research focuses on a variety of avian issues in the Russian Far East, from systematics to behavioural ecology, with an emphasis on cryptic, rare and threatened species. R. J. GUTIÉRREZ's research focuses on threatened species (particularly the spotted owl), habitat selection by animals, ecology and management of Galliformes, and conservation conflicts. 